\title{
Los procesos de validación en estudiantes ingresantes a carreras de Ciencias Naturales e Ingenierías
}

\author{
Rodolfo $D^{\prime}$ Andrea $(\cdot)$, Lisando Curia $(\cdot \cdot)$ \\ y Andrea Lavalle $(\cdots)$
}

rodolfoeliseodandrea@uca.edu.ar; lisandro.curia@faea. uncoma.edu.ar; andrea.lavalle@faea.uncoma.edu.ar (•) Universidad Católica Argentina. Facultad de Química e Ingeniería «Fray Rogelio Bacon», Rosario. $(\cdot)$ Universidad Nacional del Comahue. Facultad de Economía y Administración. Departamento de Matemática, Neuquén. (․) Universidad Nacional del Comahue. Facultad de Economía y Administración. Departamento de Estadística, Neuquén.

\begin{abstract}
Resumen
El objetivo de este trabajo es mostrar los resultados de la aplicación de una serie de ejercicios sobre validación a un grupo de 42 estudiantes ingresantes universitarios y voluntarios de carreras de grado en Ciencias Naturales e Ingenierías. Los resultados se utilizan para caracterizar la situación de este grupo de estudiantes en procesos de validación de proposiciones matemáticas. El análisis de los tipos de respuestas obtenidas es una adaptación de la clasificación de Bell (1976) e incorpora la realizada por Balacheff (2000) acerca de los tipos de prueba que suelen presentar los estudiantes.

Los resultados, en general, evidencian el desconocimiento del lenguaje matemático, lo que dificulta la lectura y en consecuencia entorpece los procesos de enseñanza y de aprendizaje en situaciones de validación. Ponen de manifiesto, además, la confusión del estudiante frente a acciones tan disímiles como verificar y demostrar.
\end{abstract}

Palabras clave: validación, estudiantes universitarios, lenguaje matemático, demostración. 


\begin{abstract}
The aim of this work is to show the results of the application of a series of exercises on validation to a group of 42 incoming college students and volunteers in careers of degree in natural sciences and engineering. The results are used to characterize the situation of this group of students in process of validation of mathematical propositions. The analysis of the kinds of answers obtained is an adaptation of the classification by Bell (1976) and also incorporates the classification done by Balacheff (2000) about the types of proof made by the students.

The results, in general, make evidence of the ignorance of the mathematical language, which complicate the reading and in consequence hinders the process of teaching and learning in situations of validation. In addition, they also show up the confusion of the students in front of actions as dissimilar as verifying and showing.
\end{abstract}

Keywords: validation, college students, mathematical language, demonstration. 